\title{
Bulbbul: Not Just Another Feminist Tale
}

\author{
P.R. Mrudula
}

Department of English, Sree Sankaracharya University of Sanskrit, Kalady, Ernakulam, Kerala, India

\begin{abstract}
Feminism has always been a relevant topic of discussion, irrespective of various forces trying to subdue it, accusing it of being overused and cliché. However, atrocities against women have failed to cease and it still thrives through multiple forms in popular media. In a country like India, religion and religious customs have always been an excuse for the patriarchal to treat women poorly. One such narrative that has recently been released is Bulbbul by Anvita Dutt, which was released online via Netflix. The movie shows the intricate linings of a rich Bengali manor and the position that women occupy in these household. Along with the issue of patriarchy, the movie also shows glimpses into a more ecological issue that exists in the globe today- the alarm of habitat loss. This paper aims to unveil the ecological aspect to the film Bulbbul. The audience sees not only the plight and experiences of a young girl married to a rich household, but also the stark reality that is the crisis of habitat loss that is faced by animals-here, a bird of the same name- worldwide due to the selfish activities of man.
\end{abstract}

Keywords-ecology, feminism, habitat loss, humanity, patriarchy.

\section{INTRODUCTION}

The latest release on Netflix that gave every advocate of feminism a party in their minds would be Bulbbul, directed by Anvita Dutt. The story and secrets of huge havelis and its lifestyles have been portrayed undoubtedly with finesse by the director. Mingling the myth of the chudail, Dutt has managed to capture the indecencies and atrocities inside privileged households. But does Anvita Dutt limit her story just to a canvas of patriarchy and feminism in the light of 19th century Bengal? Does her film just spill the dirty secrets of a Bengali manor? Bulbbul, the central character, not only portrays the plight of a woman under the lustful gazes and gropes of man, but also the fate of mother nature and her children in a world dominated by human avarice. This paper has attempted to look at the film from another point of view- that of ecology. While in plain sight it talks about the woeful incidents arising as a result of patriarchy, on a deeper analysis, one can understand the ecological problem of habitat loss lingering beneath the peripheral meaning. This paper intends to unearth and explain the film from the said dimension. Humans, knowingly or unknowingly, don the roles of Indranil and his brother Mahendra and rape the natural heritage of the land, plundering and looting it off its richness, driving the destined heirs of the globe away from their homes. This paper therefore expounds the semblance between the female protagonist Bulbbul and Mother Nature.

\section{NARRATING BULBBUL'S STORY}

The privileged in the haveli are the men, the stakeholders of patriarchy and feminine suppression. From the protagonist Bulbbul's (Tripti Dimri) marriage to an older man Indranil (Rahul Bose) to her fate at the hands of her husband and his twin brother, the audience sees her growth from an innocent little child to being a victim of male lust satiation to a powerful "chudail" who sought to deliver justice to every mistreated woman in her land. The director has unearthed the superstition of the chudail from the depths of our cultural memory and hit home the dirty concept of "big secrets" in "large manors", and how as a consequence of the chudail's good deeds, the world sentenced her death by burning her at stake. Bulbbul, the protagonist, often has a twinge of red in her attire, matching the appearance of the bird shares her name. She also carries with her a fan of peacock plume, a sign of royalty and unbounded beauty. It shows how she holds an upper hand in the haveli, however she gets killed. The actions of the human towards forests and other natural resources are no lesser than rape.

\section{THE THEATRICS AND WHAT'S LEFT UNSAID}

Bulbbul's initial phase in the movie is shown in a cool tone of blue. At the point where she resorts to drop her calmness and become the bloodthirsty chudail and a bearer of justice, the entire lighting of the film shifts to a dangerous 
hue of red- not the red that signifies fear and isolation, but the red that blares out the warning of vengeance and danger. Bulbbul's actions post the shift in light might resemble the outcry of the little bird that is facing habitat loss at an alarming rate courtesy to the greedy nature of humans. Even the character of Satya (Avinash Tiwari) who seems to want to protect Bulbbul paves the way to her eternal doom by setting her refuge on fire. Bulbbul was a deliverer of justice to many mistreated women, just like how an organism maintains the balance in the ecosystem.

\section{THE PROTAGONIST AND HER PLIGHT}

Bulbbul, from a very young age, is seen to have an affinity for perching branches of trees, an abode for birds. The character of Satya might represent the pseudo- tree hugger who in their haste to make an impression in the world, lead to nature's doom themselves. It is Dr. Sudip (Parambrata Chattopadhyay) who sees the woman for the real person that she is; who knows in depth her stories of suffering. The characters of Sudip and Satya can be seen as contrasts. Bulbbul's miserable doom happened due to unintentional but irrational decisions and actions courtesy of Satya. His character contrast in Sudip is not accidental and is a lesson to handle situations with maturity in order for its preservation.

\section{CONCLUSION}

The film although in the peripheral glance seems to discuss the perilous nature of patriarchy in Bengali havelis, on a deeper level it symbolises a great ecological crisis that not only the bulbul birds, but essentially all forest-dwellers face- of habitat loss. Both issues are ones that today we simply cannot afford to ignore. They are of immense and alarming relevance in the world that we live in today. Anvita Dutt has managed to tie two skeins of extreme relevance and execute it with finesse through her Netflix release. The cherry on the icing would be the frame in the climax, where we see the protagonist perched atop a branch, expressionless in an inferno that combusted her asylum. The trees were Bulbbul's home, where she felt absolutely at ease as compared to the strict conventions of her husband's home-A house where she was restricted by her toe ring that would "prevent girls from flying". The abovementioned frame portrays the helpless state of the bird, watching her home being destroyed to ashes by tongues of flame. The protagonist's posture in the said scene is not a mere coincidence- it resembles how a bird perches atop a branch. Dutt has brilliantly manipulated the viewer's minds to draw the resemblance between the character Bulbbul and the bird bulbul. The movie is not just a flag bearer of violence against women under toxic patriarchy. The director has also managed to symbolically unveil the grave danger that humans have put Mother Nature in and that too with striking impact. Taking the viewer through the dirty secrets in "bade havelis", Anvita Dutt has truly created a work of art relevant to the age.

\section{REFERENCES}

[1] BirdLife International. (2009, February 16). A new action plan to keep the Straw-headed Bulbul singing. https://www.birdlife.org/worldwide/news/new-action-plankeep-straw-headed-bulbul-singing

[2] Bulbbul | Netflix Official Site. (2020, June 24). Netflix. https://www.netflix.com/in/title/81029150 